\title{
Effect of selected starter cultures on production, properties and shelf life of fresh type cheese
}

\author{
Irena Barukčić1, Marta Keškić², Katarina Lisak Jakopović ${ }^{1 *}$, Sven Karlović , Rajka Božanić $^{1}$ \\ ${ }^{1}$ Laboratory for Technology of Milk and Milk products, Department of Food Engineering, Faculty of Food Technology and Biotechnology, Zagreb \\ ${ }^{2}$ Sirela dd, Bjelovar, Croatia \\ ${ }^{3}$ Laboratory for Unit Operations, Department of Process Engineering, Faculty of Food Technology and Biotechnology, Zagreb
}

*Corresponding author: klisak@pbf.hr

\begin{abstract}
The aim of this study was to examine the influence of different starter cultures including protective culture on the production and properties of fresh cheese. Fresh cheeses were produced from pasteurized milk by adding mesophilic starter cultures, mesophilic cultures and liquid rennet and by adding protective culture. All samples were analysed for acidity (active and titratable), microbiological quality, texture, colour and sensory properties during 21 days of cold storage. Additionally, milk fat, the total dry matter, total proteins and mineral content were determined in all cheese samples on the first day of storage. It could be observed that the used mesophilic culture in general did not affect chemical composition of cheese. As expected, during the storage period acidity in all cheeses decreased, while the number of microorganisms increased, whereby that changes were significantly slowed down in cheese produced by adding protective culture. Scores of sensory evaluation were high during the entire storage period for all cheeses, but samples containing cheese protective cultures achieved the highest score (18.56) at the first as well as at the last day of storage (17.98). According to all analyses, it is evident that the shelf life of cheese produced by adding protective culture has been prolonged for 12 days in comparison to samples produced without protective culture, and accounted 21 days when properly cool stored. In conclusion, the addition of protective culture might be useful for extending the shelf life and maintaining sensory properties as well as colour of fresh cheese.
\end{abstract}

Keywords: fresh cheese, protective culture, starter, composition, shelf life

\section{Introduction}

Cheese is a dairy product which has played a key role in human nutrition for centuries (Hinrichs, 2001). There are many definitions of cheese, but one of the most appropriate ones defines cheeses as fresh products or products with a different degree of maturity, produced by the separation of whey after coagulation of skimmed or partially skimmed milk, cream, whey, or a combination of these materials (Tratnik and Božanić, 2012). A wide range of available cheeses is based on mostly regional conditions and production technology, which has been adapting and optimizing over time. The main objective has always been to convert milk, which is perishable, into a product with a longer shelf-life whilst preserving its nutrients (Hinrichs, 2001). The quality of cheese, in addition to the implementation of the technological process of production, depends largely on good chemical and microbiological quality of milk (Fox et al., 2004). Compared to hard cheeses, fresh cheeses have a high water activity, which makes them susceptible to microbial spoilage, especially by yeasts and moulds which favour low $\mathrm{pH}$ values (Markov et al., 2009). In order to extend the shelf life of the product, new methods of producing fresh cheese are introduced. One of them is the addition of protective cultures. Protective cultures include selected bacterial strains such as Lactobacillus paracasei, Propionibacterium freudenreichii subsp shermanii and Lactobacillus rhamnosus that are added during production of food products to extend their shelf life and improve their ability to inhibit the growth of pathogenic organisms or microbiological spoilage agents. Bacterial strains used for production of protective cultures must be assigned by the GRAS (generally regarded as safe) status and should first be considered as an additional safety factor to enhance the microbiological safety of food. Their implementation should follow a good manufacturing practice in order to reduce the risk of growth and survival of pathogenic organisms and degradation organisms (Holzapfel et al., 1995, Miescher et al., 2004; Young and O'Sullivan, 2011).
Thus, the aim of this paper was to examine the influence of different commercially available starter cultures on chemical, physical, sensory and microbiological parameters of fresh type cheese. Also, the application of protective cultures for purposes of shelf life extension has been tested, as well as the influence of different production pathways on cheese yield.

\section{Material and methods}

\section{Materials}

Cheese was produced from milk purchased at the family farm Šmida (OPG Šmida, Vrbovec, Croatia). Commercially available starter cultures Probat 222 (Lactococcus lactis subsp. lactis, Lactococcus lactis subsp. cremoris, Lactococcus lactis subsp. lactis biovar diacetylactis and Leuconostoc mesenteroides subsp. cremoris), CHOOZIT BT01 (Lactococcus lactis subsp. lactis, Lactococcus lactis subsp. cremoris) and CHOOZIT MA11 (Lactococcus lactis subsp. lactis, Lactococcus lactis subsp. cremoris, Lactococcus lactis subsp. lactis biovar diacetylactis; all Du-Pont, Danisco, France) were used for milk coagulation. Depending on the type of the applied production process, the aforementioned mesophilic cultures were combined with rennin (Medimon d.o.o, Split, Croatia) and/or the protective culture Holdbac YM-C Plus consisting of Lactobacillus paracasei and Propionibacterium freudenreichii subsp. shermanii (Du-Pont, Danisco, France) was added.

\section{Preparation of milk for cheese production}

Prior to cheese production, raw milk was preheated to $20{ }^{\circ} \mathrm{C}$, and an aliquot was excluded for milk fat determination. The rest of the milk was then heated to a $50{ }^{\circ} \mathrm{C}$ and skimmed to milk fat content below $1.0 \%$ by a lab scale centrifugal separator (Tehtnica Milk separator, model EP-80). The skimmed milk was then pasteurized at $85-90{ }^{\circ} \mathrm{C}$ for 10 minutes, 
and cooled down to approximately $30{ }^{\circ} \mathrm{C}$ The cooled pasteurized milk was sampled and immediately analysed for microbiological quality and acidity, while an appropriate portion of the sample was cool stored for max. 12 hours within which total proteins were determined, while the samples for the total dry matter and ash content were frozen and analysed at the end of the storage period. The rest of the pasteurized milk was then divided into $2.0 \mathrm{~L}$ volumes and inoculated by the selected cultures as described in the following sections.

\section{Production and analyses of cheese samples}

In the first series of experiments, fresh cheese was produced by milk coagulation with the selected mesophilic cultures (Choosit MA 11 LYO 25 DCU, Choozit BT 01 LYO 50 DCU, Probat 222 LYO 100 DCU) that were added according to the producers' instructions.

Prior to inoculation, the $\mathrm{pH}$ value of inoculated milk was measured. Subsequently, inoculated milk was incubated at $30^{\circ} \mathrm{C}$ until pH 4.6 was reached. The obtained coagulum was cut into cubes and heated to approximately $45{ }^{\circ} \mathrm{C}$ to separate the whey. The remaining cheese curd was placed into a perforated mould and left at $4{ }^{\circ} \mathrm{C}$ to drain. After completing the process, the amount of separated whey was measured and the cheese was weighed, in order to calculate the cheese yield. The cheese was then divided into 5 equal parts and packed into plastic bags using a padlock. Packaged chees samples were kept 21 days in total, whereby sampling and analyses were done on the $1^{\text {st }}, 4^{\text {th }}, 9^{\text {th }}, 14^{\text {th }}$ and $21^{\text {st }}$ day.

The second cheese series were produced by a combined acid-enzyme coagulation by the mesophilic culture which was previously chosen to be the most appropriate in terms of cheese yield and with addition of 0.001 $\%(\mathrm{v} / \mathrm{v})$ rennin. All of the other production steps were identical as for the first series of cheese.

For the production of the third cheese series, during milk coagulation protective culture Holdbac YM-C Plus LYO 100 DCU was added according to producers' instructions.

Depending on the starter culture and the applied production process, the samples were assigned as described in Table 1.

Table 1. Description of different cheese samples investigated within the study

\begin{tabular}{|l|l|}
\hline Sample name & Production process \\
\hline BT01 & produced by CHOOZIT BT01 \\
\hline MA11 & produced by CHOOZIT MA11 \\
\hline PRO222 & produced by PROBAT 222 \\
\hline MA11+s & produced by combining CHOOZIT MA11 and rennin \\
\hline MA11+p & produced by combining CHOOZIT MA11 and protective culture Holdbac YM-C Plus \\
\hline
\end{tabular}

The evaluation of quality parameters was performed by analysing the produced cheeses for acidity $\left(\mathrm{pH},{ }^{\circ} \mathrm{SH}\right)$, the total dry matter, the content of minerals, milk fat and proteins, cheese yield, colour, textural, microbiological and sensory parameters. Active acidity $(\mathrm{pH})$ of cheese was determined by a pH meter Multi 340i (WTW, Wellheim, Germany) following the procedure described by Božanić et al. (2010) and titratable acidity according to the AOAC standard method which includes mixing grated cheese with water $\left(40^{\circ} \mathrm{C}\right)$ and filtering, and titrating an aliquot of the filtrate with $0.1 \mathrm{M} \mathrm{NaOH}$, using phenolphthalein as the indicator (AOAC Method 920.124; 2007). Titratable acidity was expressed as ${ }^{\circ} \mathrm{SH}$. The total dry matter was determined by drying samples at $102 \pm$ $2{ }^{\circ} \mathrm{C}$ until reaching a constant mass (ISO 5534:2004), while the mineral content was determined by inductively coupled plasma atomic emission spectroscopy (ICP-OES) as described in detail by Bilandžić et al. (2014). Milkfat was determined by butyrometric method according to the van Gulik method (ISO 3432:2008)., and total protein content by the Kjeldahl metod (ISO 1871:2009).

\section{Evaluation of microbiological quality of cheese samples}

Cheese samples were also subjected to analyses of microbiological parameters according to national Guidelines (2011) for microbiological criteria for foods and according to the Commission regulation (EC) 2073/2005. Thus, the total viable cell count, the viable counts of Enterobacteriaceae, coagulase-positive staphylococci, and yeasts and moulds were determined by the pour plating method. In order to prepare the initial solution, $20 \mathrm{~g}$ of cheese were dissolved in $180 \mathrm{~mL}$ of sterile $2 \%$ sodium citrate solution tempered to $45{ }^{\circ} \mathrm{C}$ (ISO 6887-5:2010). The obtained suspension was used for preparation of further dilutions. The total viable cell count was enumerated at the Tryptic Glucose Yeast Agar $\left(30{ }^{\circ} \mathrm{C} / 48-72 \mathrm{~h}\right)$, Enterobacteriaceae at the Violet Red Bile Glucose Agar $\left(37^{\circ} \mathrm{C} / 24 \mathrm{~h}\right)$, coagulase-positive staphylococci at the Baird Parker Agar with the addition of Egg Yolk emulsion $\left(37^{\circ} \mathrm{C} / 24-48 \mathrm{~h}\right)$, and yeasts and moulds at the Sabourad Dextrose agar CAF $50\left(20{ }^{\circ} \mathrm{C}\right.$ / 72 h) (all Biolife, Milan, Italy). All samples which had above $10^{3} \mathrm{cfu}$ $\mathrm{g}^{-1}$ yeasts and moulds or Enterobacteriaceae and/or above $10^{2} \mathrm{cfu} \mathrm{g}^{-1}$ coagulase positive staphylococci were eliminated from further analyses according to quality parameter set by the national Guidelines (2011) and the Commission regulation (EC) 2073/2005.

\section{Evaluation of texture and colour of cheese samples}

Hardness $\left(\mathrm{F}_{\max }\right)$ and work consumed for cheese perforation $\left(\mathrm{N}_{\mathrm{m}}\right)$ were determined by the TA.HD Plus texture analyser (SMS Stable Micro Systems Texture Analyzer, Surrey, England) equipped with a $6 \mathrm{~mm}$ diameter probe. Cheese samples were cut into $5 \times 5 \mathrm{~cm}$ cubes and tempered to room temperature prior to measurements. The prepared samples were subjected to double compression at a crosshead speed 1 $\mathrm{mm} / \mathrm{s}$ and penetration distance of $40 \mathrm{~mm}$ in both upward and downward directions with $10 \mathrm{sec}$. between two cycles. The obtained results were analysed by the Texture Exponent 32 software (version 3.0.5.0.).

Cheese colour was determined using a Spectophotometer CM-3500d (Konica Minolta, the Netherlands), whereby three colour parameters were measured - L (brightness), a (green) and b (yellow). Prior to each measurement the instrument was standardised with a black and white ceramic plate.

\section{Sensory evaluation of cheese samples}

Sensory evaluation of cheese samples was performed by a group of five specially trained panellists using a scoring system of weighted factors on a 20-point scale as described in detail by Barukčić et al. (2020) and following the recommendations of the standard ISO 22935-2, 2009. Samples of cheese were cool stored at $4{ }^{\circ} \mathrm{C}$ from the point of production and packaging, until the point of sampling and evaluation. In a room 
designed according to ISO 8589:2007 samples were opened, encoded, divided into 5 equal portions and presented simultaneously to each of the five assessors. Each sample was evaluated for colour, odour, taste and consistency, whereby each attribute could have been rated with notes from 1 to 5 . The average note of each attribute was multiplied with a predetermined weighting factor observed by the Delphi method, resulting that way in scores for each evaluated attribute. By summarizing scores of each attribute, a final score for each particular sample was obtained. The maximum score that one sample could obtain was 20 (Molnar and Örsi, 1982).

Samples that had significantly changed sensory properties and/or inadequate colour and texture were excluded from further investigations.

\section{Results and discussion}

\section{Cheese yield and chemical composition of cheese}

Depending on the type of milk coagulation technique (only by the mesophilic culture, by the mesophilic culture and rennin or mesophilic and protective culture), changes in cheese yield could be observed (Table 2). It is evident that the highest yield was obtained by the addition of mesophilic culture MA11, while the lowest yield was recorded for the addition of mesophilic culture BT01. The addition of the rennin affected the curd hardness, which results in a smaller content of water and the lower yield. The cheese yield is influenced by many other factors such as milk composition, casein content, milk composition, number of somatic cells in milk, milk pasteurization, coagulant type, vessel design, cutting strength and production parameters (Valkaj at al., 2014). From the economic aspect, cheese yield is vital for cheese makers since small differences in yield result in big differences in profits (El Gawad and Ahmed, 2011). In comparison to Minas fresh cheese with average yield of $0.19 \mathrm{~kg} \mathrm{~L}^{-1} \mathrm{milk}$ (Sant'Ana et al., 2013), the use of cultures tested within the present study results in much higher yields.

Table 2. The average yield $\left(\mathrm{kg} \mathrm{L}^{-1}\right)$, the total dry matter, protein and milk fat (\%) in different samples $(M A 11, P R O 222, B T 01, M A 11+s, P R O 222+s$, $B T 01+s, M A 11+p)$ of fresh cheese $(n=3)$

\begin{tabular}{|c|c|c|c|c|c|c|c|}
\hline \multirow{2}{*}{ Sample } & \multirow{2}{*}{$\begin{array}{l}\text { Cheese yield } \\
\left(\mathrm{kg} \mathrm{L}^{-1}\right)\end{array}$} & \multirow{2}{*}{$\begin{array}{l}\text { The total dry matter } \\
(\%)\end{array}$} & \multirow{2}{*}{$\begin{array}{l}\text { Proteins } \\
(\%)\end{array}$} & \multirow{2}{*}{$\begin{array}{l}\text { Milk fat } \\
(\%)\end{array}$} & $\mathrm{Na}$ & $\mathrm{Mg}$ & $\mathrm{Ca}$ \\
\hline & & & & & \multicolumn{3}{|c|}{$\left(\mu \mathrm{g} \mathrm{kg}{ }^{-1}\right) \times 10^{6}$} \\
\hline BT01 & 0.26 & 20.31 & 13.75 & 0.47 & 3.64 & 1.08 & 11.7 \\
\hline MA11 & 0.29 & 21.62 & 13.72 & 0.47 & 3.68 & 1.12 & 12.0 \\
\hline PRO222 & 0.27 & 21.06 & 13.76 & 0.55 & 3.65 & 1.15 & 11.9 \\
\hline $\mathrm{MA} 11+\mathrm{s}$ & 0.28 & 22.49 & 14.42 & 0.47 & 3.35 & 1.08 & 11.4 \\
\hline $\mathrm{MA} 11+\mathrm{p}$ & 0.29 & 21.79 & 14.83 & 0.47 & 3.45 & 1.04 & 11.3 \\
\hline
\end{tabular}

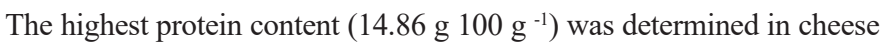
samples with the addition of protective culture (sample MA11+p). These results were similar to protein content of Minas fresh cheese (15.35 g $\left.100 \mathrm{~g}^{-1}\right)$, which was produced with the addition of mesophilic culture and rennin (Sant'Ana et al., 2013). Other cheeses had slightly lower protein

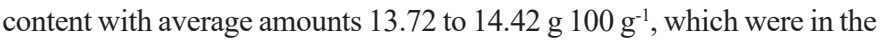
range determined by Telis-Romero et al. (2011) who reported an average

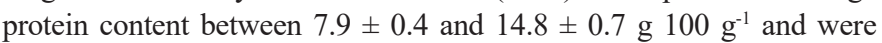
somewhat higher in comparison to average protein content of $12.5 \%$ in Cottage cheese (Fox et. al, 2017). The higher amount of proteins in fresh cheese results not only from casein, but also from a small proportion of thermosensitive whey proteins retained due to structural changes and interactions with casein caused by high pasteurisation regime (only 4-6 $\%$ of the total whey protein content) (Havranek et al., 2014; Tratnik and Božanić, 2012). The proportion of dry matter in the cheese was between 21.31 to $22.79 \%$, which was somewhat higher than in the research conducted by Telis-Romero et al. (2011) where the dry matter content was between 17.1 and $24 \%$. Prior to cheese production, the milk was skimmed to less than $1 \%$ of milk fat leading to very low $(0.47$ to 0.55 $\%$ milk fat content in cheese. Due to acidification occurring during the coagulum formation, fresh cheeses usually contain less minerals than enzyme coagulated semi-hard and hard cheeses. The most abundant mineral was Ca with contents ranging from 11.3 to $12.0 \times 10^{6} \mu \mathrm{g} \mathrm{kg}^{-1}$. According to Fox et al. (1999) the average content of $\mathrm{Ca}$ in fresh type cheeses is $90 \mathrm{mg} 100 \mathrm{~g}^{-1}$ while Holland et al. (1995) claim it to be 73 mg $100 \mathrm{~g} \mathrm{~g}^{-1}$, which implies that the use of starters tested within this study might improve $\mathrm{Ca}$ content of fresh cheese by increasing it to the average content of 113 to $120 \mathrm{mg} 100 \mathrm{~g} \mathrm{~g}^{-1}$. Among other determined minerals, higher amounts of $\mathrm{Mg}\left(3.35-3.68 \times 10^{6} \mu \mathrm{g} \mathrm{kg}^{-1}\right)$ and $\mathrm{Na}\left(1.04-1.12 \times 10^{6}\right.$ $\mu \mathrm{g} \mathrm{kg}^{-1}$ ) were also detected, which was expected according to Lucas et al. (2013), but also according to some previously published studies on fresh cheese composition (Lante et al., 2006; Manuelian et al., 2017).

During the storage of cheeses, active $(\mathrm{pH})$ and titratable acidity were also determined. There were some negligible variations with the average $\mathrm{pH}$ average between 4.54 to 4.32 , while the differences in titratable acidity were more evident ranging from 57.6 to $74{ }^{\circ} \mathrm{SH}$ (Figure 1). Nevertheless, the acidity of cheeses could be regarded as more or less stable throughout the entire storage period. Similar results were obtained by Lante et al. (2006) who investigated the $\mathrm{pH}$ of Italian fresh cheeses Crescenza and Squacquerone, which were slightly less acidic with average $\mathrm{pH}$ values between 5.05 and 5.21 . 


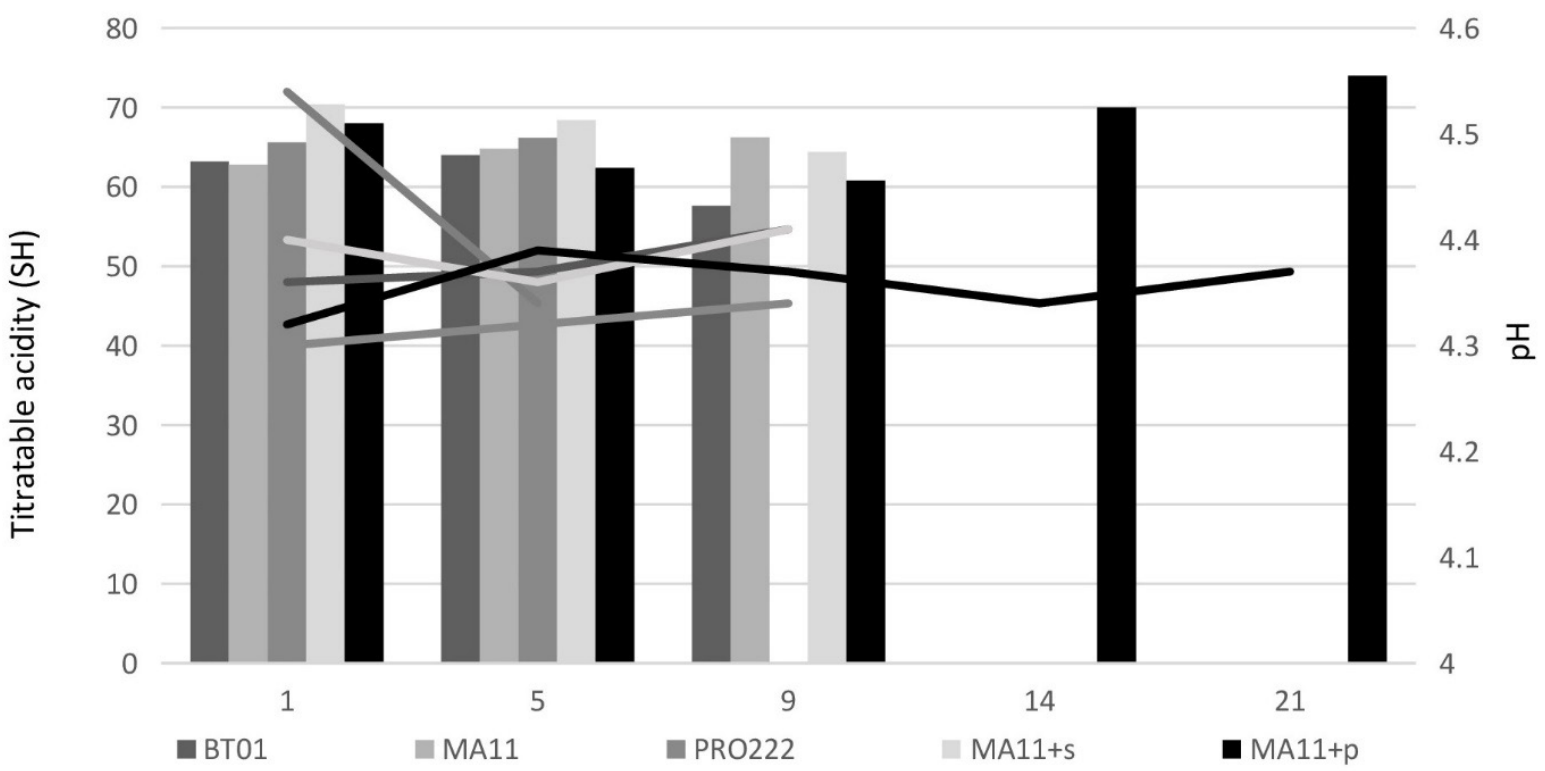

Days of storage

Figure 1. Acidity of different fresh cheese samples (MA11, PRO222, BT01, MA11+s, MA11+p) expressed as titratable (SH, shown by column) and active acidity ( $p H$, shown by line) during 21 days of cold storage $(n=3)$

From Figure 1 it is evident that the increase in $\mathrm{pH}$ values lead to a decline of ${ }^{\circ} \mathrm{SH}$ and vice versa. The acidity of the cheese affects the formation of characteristic flavours, and low $\mathrm{pH}$ values inhibit the growth of microorganisms or slow down their growth. Although it originally affects taste, this parameter is measured to control the quality of milk and dairy products. As milk acidity increases over time, by measuring this parameter, storage conditions are also controlled. The natural acidity of milk comes from the acidic properties of proteins, acid salts phosphate and citrate, and little bit less from albumin, globulin and $\mathrm{CO}_{2}$. High titratable acidity is most often the result of a higher protein content, but also higher amounts of phosphates and calcium in milk, which does not affect the decline of $\mathrm{pH}$ values (Babić, 2009). The $\mathrm{pH}$ drop in the cheese was rather caused by the production of lactic acid during the fermentation, as well as by the formation of carbonic acid arising from $\mathrm{CO}_{2}$ dissolving in acidic media. The increase in $\mathrm{pH}$ value can also be a consequence of the activity of yeasts and moulds that metabolize alkaline components into lactic acid increasing thereby the total $\mathrm{pH}$ value in fresh cheese (Kizilirmak Esmer et al., 2009).

\section{Microbiological analyses of fresh cheese}

The total number of aerobic mesophilic bacteria (data not shown) did not exceed $3.27 \mathrm{log}_{\mathrm{efu}}{ }^{-1}$ which was the highest value recorded after 9 days of cold storage of the sample BT-01. In comparison to our previous study with the same type of cheese (Barukčić et al., 2020), as well as to the results of other authors (Dermiki et al.,2008; Del Nobile et al., 2009; Kizilirmak Esmer et al., 2009) who obtained values up to $7 \mathrm{log} \mathrm{cfu} \mathrm{g}^{-1}$, the values determined in the present study were much lower. Despite that, in most of the samples either other categories of inspected microorganisms increased (Figures 2a-c) above the recommended limits or the sensory properties were unsatisfactory after 9 days of storage, which as regarded as the end of their shelf life. The only exceptions were samples MA11 and MA11+p, especially the latter one having satisfactory values of the total viable cell count even after 21 days of cold storage.

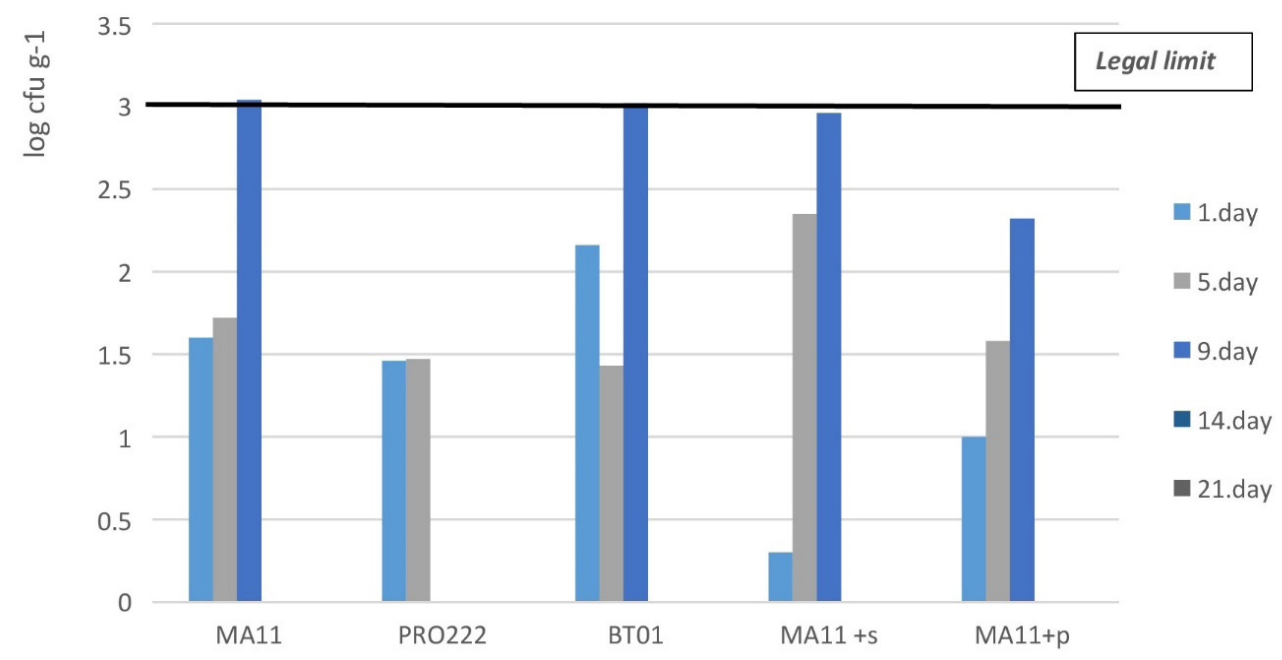


Except for cheeses that are ripening with moulds, contamination of cheese with yeast and mould is undesirable and is considered as a defect for all other types of cheeses (Havranek et al., 2014). Contamination with yeast and moulds is one of the major reasons of their spoiling. These microorganisms cause not only economic losses and reduce significantly shelf-life of the product, they may also pose a health hazard, particularly moulds that have the ability of producing mycotoxins (Filtenborg et al., 1996; Fleet, 1990; Smits and Brul, 2005). Until now, yeast and mould growth has most often been prevented by the help of chemical additives, but the use of new protective cultures is very promising, especially for the cheese industry. Figure $2 \mathrm{a}$ shows the number of growing colonies of yeasts and moulds depending on storage length. It is evident that the addition of protective cultures inhibited their growth. Penicillium spp. and Aspergillus spp. are dominant moulds in cheese spoilage without the addition of preservative, while Candida spp., Kluyveromyces marxianus and Pichia spp. are the main contaminants of immature soft cheeses (Fleet, 1990; Filtenborg et al., 1996). The heterofermentative nature of yeasts cause the formation of alcohol and $\mathrm{CO}_{2}$ in cheese, so this defect can easily be attributed to yeast, even when yeast colonies are not visible (Havranek et al., 2014). Yeasts can also be the cause of decomposition, intense gas production, appearance of foreign taste, mucus and discoloration (Fleet, 1990). Gonzalez-Fandos et al. (2000) investigated microbiological, physico-chemical and sensory characteristics of fresh cheese Cameros packed in a modified atmosphere. The results of the study showed that in the control sample (packed in a normal atmosphere) the growth of yeasts and moulds was limited. Only on the $21^{\text {st }}$ day of storage number of yeasts and moulds reached $3.73 \mathrm{log} \mathrm{cfu} \mathrm{g}^{-1}$, while on the $28^{\text {th }}$ day the number $\mathrm{s}$ was $3.34 \mathrm{log} \mathrm{cfu} \mathrm{g}^{-1}$. In the research carried out by Barukčić et al. (2020), yeasts and moulds were detected only on the $6^{\text {th }}$ day of storage and their number was $0.20 \log \mathrm{cfu} \mathrm{g}^{-1}$ while on the $9^{\text {th }}$ day it was $0.35 \log \mathrm{cfu} \mathrm{g}^{-1}$. The number of yeasts and moulds in both studies was lower than in the present study, where their number was already $0.30 \log$ cfu $\mathrm{g}^{-1}$ up to $2.16 \log$ cfu g $^{-1}$ for the first day of storage.

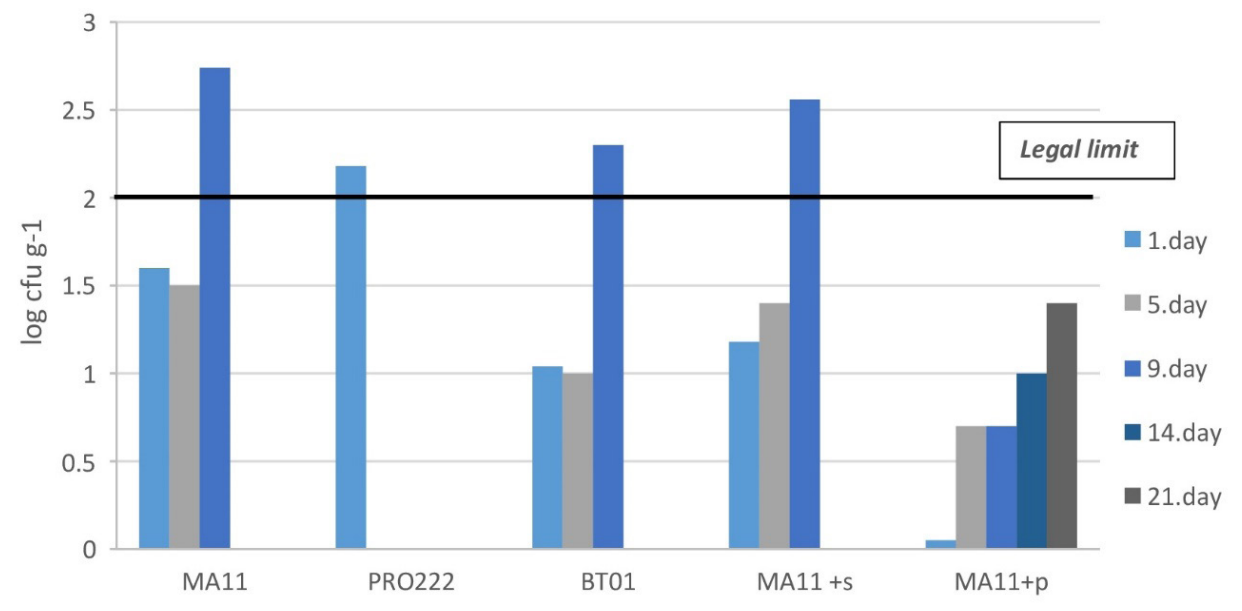

Figure 2b. The average number (log $\left.c f u \mathrm{~g}^{-1}\right)$ of coagulase positive Staphylococus aureus in samples of fresh cheese (MA11, PRO222, BT01, MA11+s, MA11+p) during 21 days of cold storage $(n=3)$

The ability of Staphylococcus aureus species to grow in fresh cheeses is inhibited by the rapid formation of high concentrations of lactic acid and the thereof resulting low pH of cheese (Samaržija et al., 2007). However, a large number of Staphylococcus aureus strains are capable of generating extracellular thermostable enterotoxins, which retain their biological activity even after heat treatment of milk and / or cheese grains (Walstra et al., 1999). Due to thermoresistence, staphylococcal enterotoxins are considered as the highest microbiological risk in fresh cheese even after heat treatment $\left(100^{\circ} \mathrm{C} / 30 \mathrm{~min}\right)$. They are resistant to most proteolytic enzymes of the human digestive tract and proteolytic enzymes of the cheese, and they are resistant to a low $\mathrm{pH}$ value of the human stomach (Havranek et al., 2014). Figure 2b. shows the average viable counts of coagulase positive Staphylococcus aureus during the storage period. It is obvious that the addition of protective culture to the mesophilic culture MA11 has extended the shelf-life. On the $21^{\text {st }}$ day of storage cheese samples MA11 and BT01 contained higher values of coagulase positive staphylococci than allowed by the relevant legislation (EC 2073/2005, National Microbiological Food Criteria Guide, 2011). Such results indicated the end of the shelf life of these products and samples were no longer analysed.

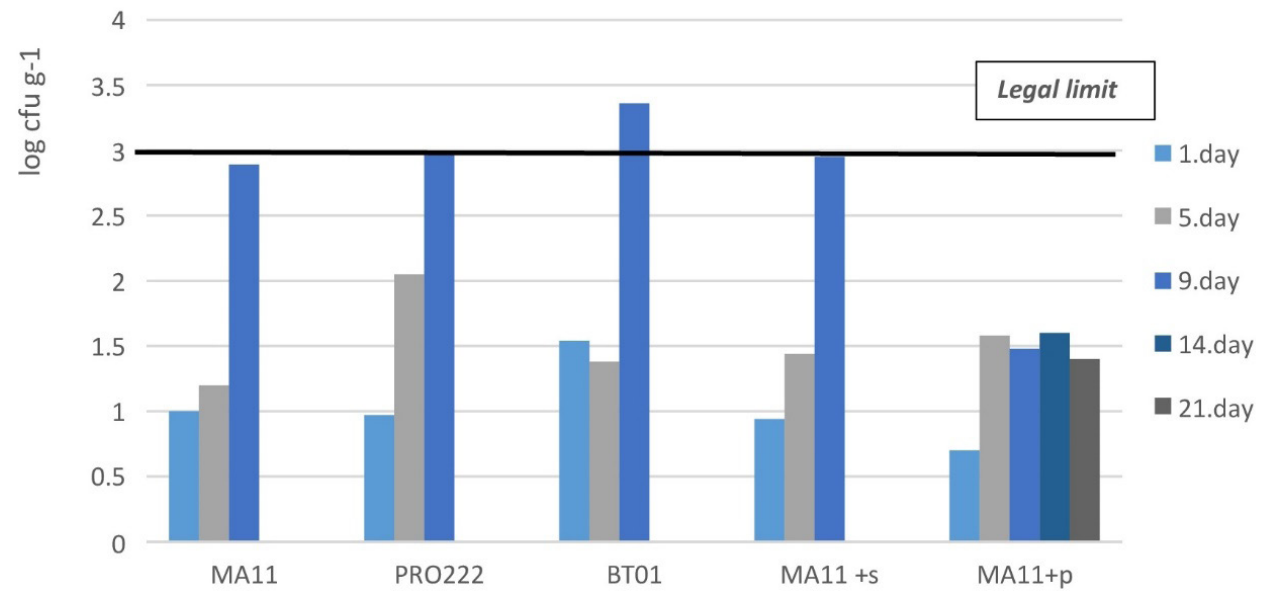

Figure 2c. The average number (log $\left.c f u g^{-1}\right)$ of Enterobacteriaceae in samples of fresh cheese (MA11, PRO222, BT01, MA11+s, MA11+p) during 21 days of cold storage $(n=3)$ 
Figure 2c shows the total number of Enterobacteriaceae which are obviously present within the limits of tolerance. According to Giammanco et al. (2011), the quality of milk cheese as well as the hygienic conditions during production, packaging and handling can influence the amount of Enterobacteriaceae in cheese samples. Different types of Enterobacteriaceae have the ability to decarboxylate lysine and ornithine, which is leading to the production of biogenic amines cadaverine and putrescine. After the $5^{\text {th }}$ day of the storage of cheese produced by adding the mesophilic culture PRO22, sensory evaluators described it to have a fecal taste, which might have been caused by biogenic amines cadaverine and putrescine according to Ardö (2006). Goznalez-Fandos et al. (2000) analysed in their research fresh cheese Cameros for the total number of enterobacteria. Fecal coliforms were detected only after 14 days of cold storage when their number was 1.18 $\log$ cfu g ${ }^{-1}$, and the maximum level was reached on the $21^{\text {st }}$ day when the number was $1.97 \log \mathrm{cfu} \mathrm{g}^{-1}$. In the present study, enterobacteria were detected already on the first day and their number varied from 0.40 $\log$ cfu g $\mathrm{g}^{-1}$ to up to $1.95 \log \mathrm{cfu} \mathrm{g}^{-1}$, which could be related to cheese milk contamination or to contamination of equipment used in cheese production. However, taking into consideration the obtained values for Enetrobacteriaceae in general, all of the produced cheese samples could be regarded to be of adequate quality for 9 days of cold storage (Figure 2c).

\section{Sensory analysis}

Sensory analysis of fresh cheese was carried following a 20-weightedsystem sensory analysis template. During the analysis, taste, odour, texture, after in the mouth and surface appearance were evaluated. Each of these properties was evaluated with a score of 1 to 5 . The lack of such an evaluation was corrected by applying the significance factor $\left(\mathrm{F}_{\mathrm{v}}\right)$. Data processing showed that the samples were of good taste, and that none of the samples received a total score lower than 16. It can be seen that some cheeses achieved scores with aging. In a study conducted by Gonzalez-Fandos et al. (2000), the sensory characteristics of the cheese were not satisfactory after 7 days of cold storage. The development of flavours in fermented dairy products, especially the cheeses, is the result of a series of (bio) chemical processes supported by enzymes originating from starter cultures (Smit et al., 2005). In the present study lactic acid contributed the most to the typical fresh cheese taste by controlling the growth of undesired microorganisms (Kosikowski, 1997). The enzymatic degradation of casein into peptides and amino acids, which are then the main precursors for the formation of volatile aromatic compounds, is crucial for the formation of odours that are contributing to the sensory perception of cheese (Smit et al., 2005). It is difficult to distinguish the best sample in relation to sensory evaluation, but according to the obtained results that might be sample MA11+p with the addition of the protective culture since it achieved a highest total score 18.56 on the first day of storage, and maintained the high scores throughout the entire storage period (Figure 3).

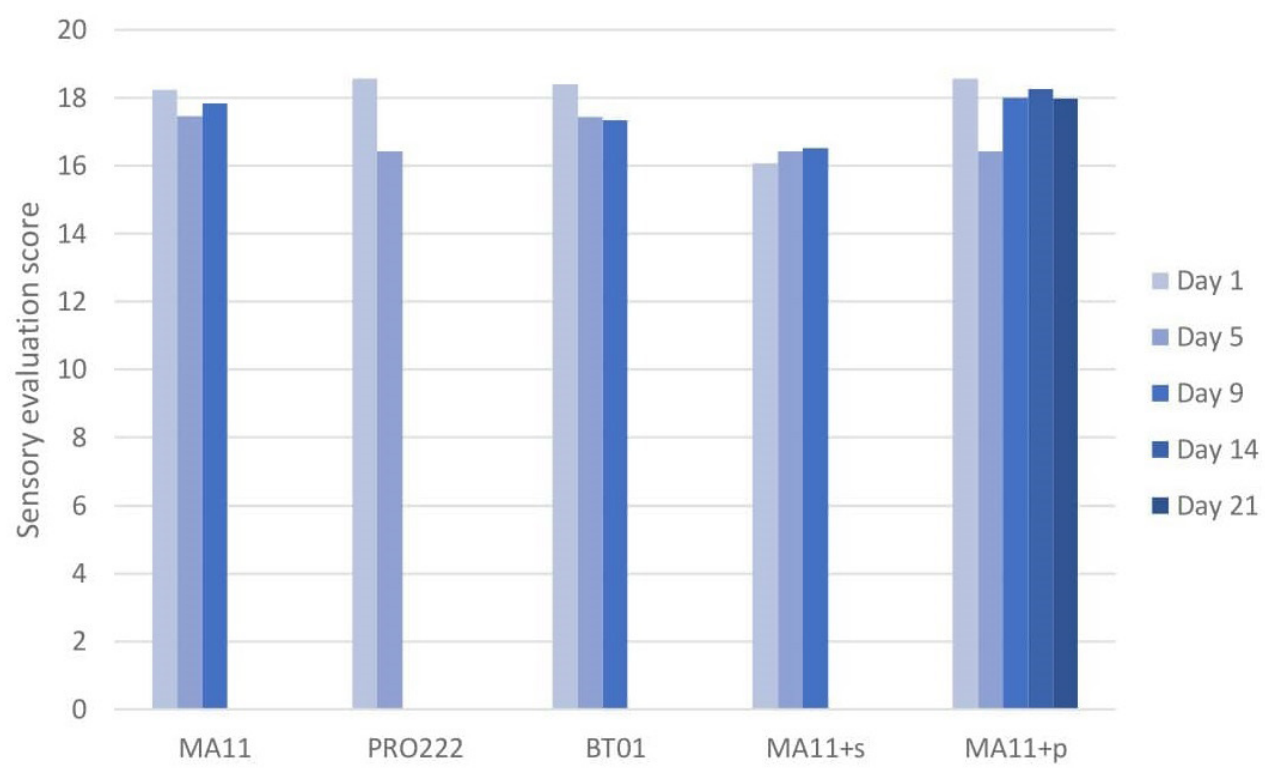

Figure 3. Total scores of sensory evaluation for different cheese samples (MA11, PRO222, BT01, MA11+s, MA11+p) during 21 days of cold storage ( $n=3$ )

From the results presented in Figure 3, a general trend could be observed indicating that the cheeses produced with addition of mesophilic culture achieved better average score than cheeses produced with addition of renin and protective cultures. It could also be observed (data not shown) that all cheeses received high scores for colour which did not change during storage, which was confirmed by colorimetric measurements too (Table 4). These results are in line with those of Sant'Ana et al. (2013) where colour changes were minimal during storage. According to Wadhwani and McMahon (2012), the colour of the cheese can change the perception of taste for consumers. During the storage of cheeses there were also no intense changes in consistency whereby the obtained scores remained constant. The most significant changes during storage were noticed in taste and odour. Looking at the individual sensory properties, the highest scores for taste were having the cheeses MA11 and MA11 $+p$. These cheeses also had the highest share of milk fat that positively influenced the cheese flavour. It dissolves in cheese compounds that were formed by hydrolytic decomposition of fat and proteins and prevents formation and tightness of solid protein rubber matrix, which makes continuous phase of cheese, and which would have gummy consistency without milk fat in its structure (Havranek er al., 2014).

\section{Texture and colour}

As previously highlighted, the texture of cheese depends on various interactions between different factors like cheese composition, manufacturing process or ripening conditions. In that manner, textural properties of acid coagulated fresh cheeses are greatly influenced by the acidity. More precisely, $\mathrm{pH}$ values higher than 4.7 will result in soft texture and lack of flavour, while $\mathrm{pH}$ values lower than 4.6 will cause a grainy, chalky texture, whey separation and excessively acid flavour (Lucey, 2017). 
Table 3. The average hardness $\left(F_{\text {max }}\right)$ and work consumed for cheese perforation $\left(N_{m}\right)$ of different fresh cheese samples (MA11, PRO222, BT01, $M A 11+s, M A 11+p)$ during 21 days of storage $(n=3)$

\begin{tabular}{|c|c|c|c|c|c|}
\hline \multirow{2}{*}{ Sample } & 1.day & 5.day & 9.day & 14.day & 21.day \\
\hline & \multicolumn{5}{|c|}{$\mathrm{F}_{\text {max }}(\mathrm{N})$} \\
\hline MA11 & 0.874 & 0.922 & 1.458 & - & - \\
\hline PRO222 & 1.272 & 0.957 & 1.637 & - & - \\
\hline ВT01 & 1.042 & 1.122 & - & - & - \\
\hline $\mathrm{MA} 11+\mathrm{s}$ & 1.097 & 1.077 & - & - & - \\
\hline MA11+p & 1.088 & 1.232 & 1.341 & 1.657 & 1.826 \\
\hline \multicolumn{6}{|c|}{$\mathrm{N}_{\mathrm{m}}$} \\
\hline MA11 & 0.008 & 0.004 & 0.003 & - & - \\
\hline PRO222 & 0.009 & 0.007 & 0.013 & - & - \\
\hline BT01 & 0.010 & 0.008 & - & - & - \\
\hline MA11 +s & 0.018 & 0.005 & - & - & - \\
\hline $\mathrm{MA} 11+\mathrm{p}$ & 0.008 & 0.004 & 0.009 & 0.013 & 0.017 \\
\hline
\end{tabular}

Textural characteristics of cheese are determined by the combined structural properties of protein matrix and fat droplets that are incorporated into the matrix (Lobato-Calleros et al., 2001). From Table 3 it is apparent that cheese hardness $\left(\mathrm{F}_{\max }\right)$ increases over time, so maximal force for cheese perforation grows. Accordingly, the highest force $\mathrm{N}_{\mathrm{m}}$ required for cheese breaking was required in the sample MA11+p that was produced with the addition of protective culture and was $1.8256 \mathrm{~N}$. Such results might be explained by changes in protein matrix leading to strengthening the bonds and narrowing the gel structure which caused whey separation which was visible during sampling and sensory evaluation. Consequently, the elasticity of cheese decreased, which was perceived during sensory evaluation. Opposite to that, in the research carried out by Kizilmark Esmer et al. (2009) the maximum force for cheese perforation decreased over time, which was explained by increasing the amount of proteolytic products indicating the weakening of protein bonds in the coagulum.

Table 4. Average values for colour parameters (L-light, a-green, b-yellow) in different samples of fresh cheese (MA11, PRO222, BT01, MA11+s, $M A 11+p)$ measured during 21 days of cold storage $(n=3)$

\begin{tabular}{|c|c|c|c|c|c|c|}
\hline & Day of storage & BT01 & MA11 & PRO222 & MA11+s & MA11+p \\
\hline \multirow{5}{*}{$\mathrm{L}$} & 1 & 94.98 & 95.22 & 95.70 & 94.42 & 94.78 \\
\hline & 5 & 90.87 & 95.29 & 95.04 & 94.94 & 95.52 \\
\hline & 9 & 94.84 & 94.48 & - & 94.03 & 94.95 \\
\hline & 14 & - & - & - & - & 95.61 \\
\hline & 21 & - & - & - & - & 94.81 \\
\hline \multirow{5}{*}{$\mathrm{a}$} & 1 & -1.39 & -1.27 & -1.44 & -1.03 & -1.38 \\
\hline & 5 & -1.36 & -1.39 & -1.43 & -1.02 & -1.24 \\
\hline & 9 & -1.28 & -1.34 & - & -1.08 & -1.31 \\
\hline & 14 & - & - & - & - & -1.29 \\
\hline & 21 & - & - & - & - & -1.28 \\
\hline \multirow{5}{*}{$\mathrm{b}$} & 1 & 8.90 & 8.59 & 8.84 & 9.71 & 9.32 \\
\hline & 5 & 8.48 & 8.8 & 8.77 & 9.60 & 9.06 \\
\hline & 9 & 8.81 & 8.49 & - & 9.94 & 9.22 \\
\hline & 14 & - & - & - & - & 8.91 \\
\hline & 21 & - & - & - & - & 9.14 \\
\hline
\end{tabular}

Table 4 shows that there was no significant change in colour in cheese samples during storage. The colour of the cheese could be described as white, and its intensity didn't change much during the storage period. However, as the storage period went by, a small amount yellow shade could be noticed, which is evident in the increase of $b$ values. According to Saldo et al. (2002) changes in cheese colour are associated with changes in microstructure after pasteurization. In some samples there was probability of degradation of carotenoid and riboflavin due to exposure to light, and because of it decreased $\mathrm{L}$ value decreased
(Barukčić et al., 2020). The presence of oxygen leads to oxidation which is evident in colour change (Del Nobile et al., 2009). Values L, $a$ and $b$ were in most cases decreasing, except for cheese MA11 $+p$ where L and a value were in growth. Such results might be related to the inhibitory effect of protective cultures on oxidation. More precisely, protective cultures produce specific metabolites such as organic acids (milk, acetic and propionic) which act competitively with agents that cause spoilage of nutrients (Young and Sullivan, 2011). 


\section{Conclusions}

The aim of this study was to investigate the influence of different commercially available starter cultures including protective starters, on selected process parameters, quality characteristics and shelf life of fresh acid coagulated cheese. According to all of the obtained results, the choice of the starter culture did not affect chemical composition and texture of cheese. However, the addition of renin caused a higher density of curd, lower yield and a smaller amount of retained water in cheese. Thus, the highest yield of cheese was obtained by the addition of mesophilic culture MA11, while the lowest yield was recorded when mesophilic culture BT01 was used in combination with renin. Microbiological analyses showed that the shelf life of cheese produced by adding protective culture has been prolonged for 12 days in comparison to the control sample, and was 21 days. In accordance with that were also the results of colour measurements indicating the least changes in that sample. Scores of sensory evaluations were high for all days of storage and average grade was from 16.43 to 18.56 . Cheese with the addition of mesophilic cultures solely had higher scores than cheeses with the addition of mesophilic culture and renin, whereby the sample MA11+p with the addition of protective culture achieved the highest scores during the entire storage period. In conclusion, the use of protective cultures might be beneficial not only in terms of prolonging shelf life, but also for improving sensory properties and colour of fresh acid coagulated cheese.

\section{Acknowlegement}

This study has been performed as a part of preliminary investigations for the project "Modification of cheese ripening process and development of whey based products - SIRENA" project co-financed by the European Union from the European Structural and Investment Funds in the financial period 2014-2020 and the Operational Programme Competitiveness and Cohesion 2014-2020.

\section{References}

AOAC 920.124-1920, Acidity of cheese. Titrimetric method

Babić M. (2009) Utjecaj dodatka meda na fermentaciju kravljeg, kozjeg i sojinog mlijeka baterijom Lactobacillus casei - 01. Diplomski rad, Sveučilište Josipa Jurja Strossmayera u Osijeku, Prehrambeno-tehnološki fakultet Osijek, Osijek.

Barukčić I., Ščetar M., Marasović I., Lisak Jakopović K., Galić K., Božanić R. (2020) Evaluation of quality parameters and shelf life of fresh cheese packed under modified atmosphere. Journal of Food Science and Technology, 57 2722-2731. https://doi.org/10.1007/s13197-020-04308-6

Bilandžić N., Sedak M., Đokić M., Božić Đ., Solomun Kolanović B., Varenina I. (2014) Trace elements content in cheese, cream and butter. Mljekarstvo, 64 (3) 150-158. https://doi.org/10.15567/mljekarstvo.2014.0302

Božanić R., Jeličić I., Bilušić T. (2010) Analize mlijeka i mliječnih proizvoda (Analyses of milk and dairy products), Plejada, Zagreb.

De Fátima Poças M., Pintado M. (2010) Packaging and the Shelf Life of Cheese. U: Food packaging and shelf life a practical guide (Robertson, G. L.), Taylor \& Francis Group, Boca Raton, USA, pp 103-126.

Del Nobile M.A., Conte A., Incoronato A.L., Panza O. (2009) Modified atmosphere packaging to improve the microbial stability of Ricotta. African Journal of Microbiological Research, 3 (4) 137-142.

Dermiki M., Ntzimani A., Badeka A., Savvaidis I.N., Kontominas M.G. (2008) Shelf-life extension and quality attributes of the whey cheese "Myzithra Kalathaki" using modified atmosphere packaging. LWT-Food Science and Technology, 41 (2) 284-294. https://doi.org/10.1016/j.1wt.2007.02.014 EC 2073/2005 Commission Regulation (EC) of 15 November 2005 on microbiological criteria for foodstuffs.

El-Gawad M.A., Ahmed N.S. (2011) Cheese yield as affected by some parameters review. Acta Scientiarum Polonorum Technologia Alimentaria, 10 (2) $131-153$.

Filajdić M., Ritz M., VojnovićV. (1988) Senzorska analiza mliječnih proizvoda. Mljekarstvo, 38 295-301.

Filtenborg O.J., Frisvad C., Thrane U. (1996) Moulds in food spoilage. International Journal of Food Microbiology, 33 85-102. https://doi. org/10.1016/0168-1605(96)01153-1

Fleet G. H. (1990) Yeast in dairy products. Journal of Applied Bacteriology, 68 199-211. https://doi.org/10.1111/j.1365-2672.1990.tb02566.x

Fox P.F., McSweeney P.L.H., Cogan T.M., Guinee T.P. (2004) Cheese: Chemistry, Physics and Microbiology, Major Cheese Groups, 3rd Ed., Academic Press London, UK.

Fox, P.F., McSweeney P.L.H., Cogan, T.M., Guinee, T.P. (2017) Fundamentals of Cheese Science, 2.nd Ed., Springer, New York

Giammanco G.M., Pepe A., Aleo A., D’Agostino V., Milone S., Mammina C. (2011) Microbiological quality of Pecorino Siciliano "primosale" cheese on retail sale in the street markets of Palermo. The New Microbiologica: official journal of the Italian Society for Medical Virology (SIVIM), 34 (2) $179-185$.

Gonzalez-Fandos, E., Sanz, S., Olarte, C. (2000) Microbiological, physicochemical and sensory characteristics of Cameros cheese packaged under modifed atmospheres. Food Microbiology, 17 407-414. https://doi.org/10.1006/fmic.2000.0338

Gutierrez -Mendez N., Trancoso-Reyes N., Yarely Leal-Ramos M. (2013) Texture profile analysis of Fresh cheese and Chihuahua cheese using miniature cheese models. Technociencia Chihuahua, 7 65-74.

Hati S., Mandal S., Prajapati J.B. (2013) Novel starters for value added fermented dairy products. Current Research in Nutrition and Food Science Journal, 1 (1) 83-91. http://dx.doi.org/10.12944/CRNFSJ.1.1.09

Havranek J., Kalit S., Antunac N., Samaržija D. (2014) Sirarstvo, Hrvatska mljekarska udruga, Zagreb.

Hinrichs J. (2001) Incorporation of whey proteins in cheese. International Dairy Journal, 11 495-503.

https://doi.org/10.1016/S09586946(01)00071-1

ISO 1871:2009 Food and feed products - General guidelines for the determination of nitrogen by the Kjeldahl method.

ISO 3432:2008 Cheese — Determination of fat content — Butyrometer for Van Gulik method.

ISO 5534:2004 Cheese and processed cheese - Determination of the total solids content (Reference method).

ISO 6887-5:2010 Microbiology of food and animal feeding stuffs — Preparation of test samples, initial suspension and decimal dilutions for microbiological examination - Part 5: Specific rules for the preparation of milk and milk products

Holland B., Welch A.A., Unwin I.D., Buss D.H., Paul A.A., Southgate D.A.T. (1995) The Composition of Foods, 5th Edition. Royal Society of Chemistry and Ministry of Agriculture, Fisheries and Food, London, UK.

Holzapfel W.H., Geisen R., Schillinger U. (1995) Biological preservation of foods with reference to protective cultures, bacteriocins and food-grade enzymes. International Journal of Food Microbiology, 24 (3) 343-362. https://doi.org/10.1016/0168-1605(94)00036-6

Kizilirmak Esmer O., Balkir P., Seckin K.A., Irkin R. (2009) The Effect of Modified Atmosphere and Vacuum Packaging on the Ohysichemical, 
Microbiological, Sensory and Textural Properties of Crottin de Chavignol Cheese. Food Science and Technology Research, 15 (4) 367-376. https:// doi.org/10.3136/fstr.15.367

Kosikowski F.V., Mistry V.V. (1997) Cheese and Fermented Milk Foods. 3.rd Ed. FV Kosikowski LLC, USA.

Lante A., Lomolino G., Cagnin M., Spettoli P. (2006) Content and characterisation of minerals in milk and in Crescenza and Squacquerone Italian fresh cheeses by ICP - OES. Food Control, 17229 - 233. https://doi.org/10.1016/j.foodcont.2004.10.010

Lobato-Calleros C., Robles-Martínez J. C., Caballero-Pérez J. F., Aguirre-Mandujano E., Vernon-Carter E. J. (2001) Fat replacers inlow-fat Mexican Manchego cheese. Journal of Texture Studies, 32 1-14. https://doi.org/10.1111/j.1745-4603.2001.tb01030.x

Lucas, A., Andueza, D., Rock, E., Martin B. (2008) Prediction of dry matter, fat, pH, vitamins, minerals, carotenoids, total antioxidant capacity, and colour in fresh and freeze-dried cheeses by visible-near-infrared reflectance spectroscopy. Journal of Agricultural and Food Chemistry, 56 6801-6808. https://doi.org/10.1021/jf800615a

Lucey, J.A. (2017) Formation, Structural Properties, and Rheology of Acid-Coagulated Milk Gels. In: Paul L.H. McSweeney, P.L.H., Fox, P.H., Cotter, P.D., Everett, D.W. (Eds), Cheese - Chemistry, Physics and Microbiology, 4.th edition, Academic Press, USA, pp 176-197. https://doi.org/ 10.1016/B978-0-12-417012-4.00007-7

Manuelian C.L., Currò S., Visentin G., Penasa M., Cassandro M, Dellea C., Bernardi M., De Marchi M. (2017) Technical note: At-line prediction of mineral composition of fresh cheeses using near-infrared technologies. Journal of Dairy Science, 100 (8) 6084-6089. https://doi.org/10.3168/ jds.2017-12634

Markov K., Frece, J., Čvek D., Delaš F. (2009) Listeria monocytogenes i drugi kontaminanti u svježem siru. Mljekarstvo, 59 (3) $225-231$.

Miescher Schwenninger, S., Meile L. (2004) A mixed culture of Propionibacterium jensenii and Lactobacillus paracasei subsp. paracasei inhibits food spoilage yeasts. Systematic Applied Microbiology, 27 229-237. https://doi.org/10.1078/072320204322881853

Panday A., Joshi V.K., Nigam P., Soccol C.R. (1999) Enterobacteriaceae, coliforms and E. coli. In: Encyclopedia of Food Microbiology, (Robinson, R.K., Batt, C.A., Patel, P.D. ured.), Accademic Press, Amsterdam, pp 604-610.

Sant'Ana A.M.S., Bezerril F.F., Madruga,A.S.M., Batista A.S.M., Magnani M., Souza E.L., Queiroga R.C.R.E. (2013) Nutritional and sensory characteristics of Minas fresh cheese made with goat milk, cow milk, or a mixture of both. Journal of Dairy Science, $967442-7453$. https://doi. org/10.3168/jds.2013-6915

Saldo, J., Sendra, E., Guamis, B. (2002) Color changes during ripening of high pressure treated hard caprine cheese. High Pressure Research, 22, 659-663. https://doi.org/10.1080/08957950212460

Samaržija D., Damjanović S., Pogačić T. (2007) Staphylococcus aureus u siru. Mljekarstvo, 57 (1) 31 - 48.

Smit G., Smit B.A., Wim J.M., Engels J.M. (2005) Flavour formation by lactic acid bacteria and biochemical flavor profiling of cheese products. FEMS Microbiological Letters, 29 591-610. https://doi.org/10.1016/j.fmrre.2005.04.002

Smits G.J., Brul S. (2005) Stress tolerance in fungi - to kill a spoilage yeast. Currents Opinion in Biotechnology, 16 225-230. https://doi.org/10.1016/j. copbio.2005.02.005

Telis-Romero J., Váquiro H.A., Bon J., Benedito J. (2011) Ultrasonic assessment of fresh cheese composition. Journal of Food Engineering, 103 137-146. https://doi.org/10.1016/j.jfoodeng.2010.10.008

Tratnik, Lj., Božanić, R. (2012) Mlijeko i mliječni proizvodi, Hrvatska mljekarska udruga, Zagreb.

Valkaj K., Kalit S., Salajpal K., Zubović M., Marković T. (2014) Chemical and Microbiological Characterization of Turoš Cheese. Agriculturae Conspectus Scientificus, 79 201-207.

National Guide for Microbiologic criteria for foods (2009) Ministarstvo poljoprivrede, ribarstva i ruralnog razvoja, Zagreb.

Wadhwani R., McMahon D. J. (2012) Colour of low-fat cheese influences flavour perception and consumer liking. Journal of Dairy Science, 95 2336-2346. https://doi.org/10.3168/jds.2011-5142

Walstra P., Geurts T. J., Noomen A., Jellema A., Van Boekel M. A. J. S. (1999) Microbiology of Milk. U: Dairy Technology, Principles of Milk Properties and Processes, (Dekker, M., Ed.) Inc, New York, pp 149-170.

Young N.W.G., O'Sullivan G.R. (2011) The influence of ingredients on product stability and shelf life. U: Food and beverage stability and shelf life (Kilcast, D., Subramaniam, P., Eds.) Woodhead Pub, Oxford, pp 132-183. https://doi:10.1533/9780857092540.1.132 